Razprava se posveča trem dramam Simone Semenič, ki so izšle v knjigi z naslovom Me slišiš? (2017). Na prvi pogled gre za znano avtoričino pisavo brez ločil in velikih začetnic ter brez očitnega deljenja na didaskalije in dialog, vendar se v vsebinskem smislu bistveno razlikuje od preostalega avtoričinega opusa, saj so to avtobiografska besedila, ki ponovno vzpostavljajo dramsko osebo in bolj ali manj razvidno dramsko dejanje. Razprava se osredotoča na vprašanji, ali gre še za ne več dramska besedila in kako je z reprezentacijo in dogodkovnostjo v njih. $Z$ analizo formalnih in vsebinskih lastnosti besedil, natančneje z analizo dramske osebe, razmerja med dialogom in monologom ter dramskega dejanja, razprava pokaže, da ti teksti vzpostavljajo prepoznavne dramske subjekte in dovolj trdno dramsko dejanje. S tem se odmikajo od ne več dramskih tekstov, kot jih definira Gerda Poschmann, čeprav je njihova dediščina še močno prisotna npr. v fragmentarnem načinu pisanja.

Ključne besede: Simona Semenič, Me slišiš?, ne več dramski tekst, dramski tekst, Birgit Haas

Gašper Troha je doktoriral na Oddelku za primerjalno književnost in literarno teorijo Filozofske fakultete Univerze v Ljubljani. Ukvarja se s sociologijo literature, še posebej z vprašanji sodobne svetovne in slovenske dramatike in gledališča. Predava na Filozofski fakulteti in deluje kot raziskovalec na AGRFT Univerze v Ljubljani. Objavljal je v številnih domačih in tujih znanstvenih revijah. Med drugim je soavtor knjig Zgodovina in njeni literarni žanri (Cambridge Scholars Publishing, 2008), Literarni modernizem v »svinčenih« letih (Študentska založba, 2008) in Lojze Kovačič: življenje in delo (Študentska založba, 2009). Leta 2015 je izdal monografijo Ujetniki svobode o razvoju slovenske dramatike in gledališča v socializmu.

gasper.troha@guest.arnes.si 


\section{Me slišiš? Simone Semenič in vprašanje ne več dramske pisave ${ }^{1}$}

Gašper Troha

FF Univerze v Ljubljani, AGRFT Univerze v Ljubljani

\section{Uvod}

Simona Semenič, dandanes verjetno najvznemirljivejša slovenska dramatičarka, katere opus zaznamuje nenehno poigravanje s formo in ga običajno označujemo kot ne več dramsko pisavo (prim. Leskovšek in Toporišič, »(Ne več) dramski«), je leta 2017 pri založbi Zrakogled izdala knjigo Me slišišs?, v kateri je objavila tri svoje avtobiografske performanse: jaz, žrtev (2007), še me dej (2009) in drugič (2014). Vse tri je tudi sama izvedla v letih, ko so besedila nastala.

Na prvi pogled gre za znano avtoričino pisavo brez ločil in velikih začetnic ter brez očitnega deljenja na didaskalije in dialog. $V$ tekstu avtorica nenehno polemizira $\mathrm{z}$ občinstvom, ga torej jemlje kot sokreatorja uprizoritve in od njega zahteva aktivno vlogo. $\mathrm{V}$ tem bi torej lahko videli odmik od reprezentacije $\mathrm{k}$ dogodkovnosti, ki je značilna za postdramsko gledališče (Lehmann) in ne več dramske tekste (Poschmann), a je že avtorica v uvodu h knjigi zapisala, da gre za »avtobiografska besedila, za katera sem zdaj, po ponovnem branju, ugotovila, da se v njih ukvarjam predvsem z avtoriteto. Skozi osebne pripetljaje ti trije teksti bolj ali manj bentijo čez sistem, v katerem trenutno živimo« (10). Prav slednje bržkone kaže na odmik od siceršnjega avtoričinega pisanja, ki nas napeljuje na naslednja vprašanja.

So to še ne več dramska besedila? Kako je z reprezentacijo in dogodkovnostjo v njih?

Nekateri raziskovalci so že opazili, da gre za drame, ki v opusu Simone Semenič odstopajo od siceršnjega vzorca. Tako Ivana Zajc v svoji raziskavi monodrame in avtobiografskih elementov $v$ dramah Simone Semenič s pomočjo stilometrične analize ugotovi, da prav obravnavana besedila tvorijo posebno skupino, ki se po deležu monoloških prvin »ločijo od preostalih, gostija se razvrsti mednje, a je najbolj oddaljena od drugih obravnavanih besedil« (86).

Tudi Tomaž Toporišič v svojem članku o dramski pisavi po postdramskem izpostavlja

1 Članek je nastal v okviru raziskovalnega programa Gledališke in medumetnostne raziskave P6-0376, ki ga financira Javna agencija za raziskovalno dejavnost Republike Slovenije iz državnega proračuna. 
dejstvo, da drame Simone Semenič presegajo ne več dramsko pisavo in ustvarjajo še kako dramatične učinke:

Dialoško obliko sicer vztrajno predeluje $\mathrm{v}$ družbi $\mathrm{z}$ raznorodnimi besedilnimi strategijami: od odrskih smernic do opisov, ki so bližje romanu in prozi, pripovednih, esejističnih, teoretičnih in drugih tehnik, ki občinstvo opominjajo, da to, kar bere ali gleda, ni več realen dialog. Toda pri tem proizvede izrazito dramatične učinke, ki bi jih Haasova najbrž imenovala »dramatično dramske«. (»Dramska« 114)

Da bi lahko raziskali, kako se Simona Semenič v Me slišiš? giblje med postdramsko in dramsko pisavo, kaj to pomeni za vprašanje reprezentacije in prezence oz. zakaj je ta pisava že na prvi pogled drugačna od dram, ki temeljijo na delitvi na dialog in didaskalije, dramskem dejanju, zapletu itd., obenem pa je še kako dramatična in relevantna, se bomo oprli na misel Birgit Haas o ponovno dramskih besedilih ter seveda natančno analizirali izbrana besedila Simone Semenič.

\section{Ne več dramska in dramska gledališka pisava}

Nika Leskovšek v spremni besedi k izdaji Treh dram Simone Semenič zelo dobro opiše zagato raziskovalke ob poskusu kategorizacije obravnavanih besedil. Tu najprej ugotavlja, da je zelo očitno dejstvo, da Simona Semenič odstopa od Szondijevega koncepta absolutne drame in uvaja celo serijo postopkov epizacije, ki bi jo na prvi pogled postavili v polje postdramskega oz. ne več dramske pisave. Vendar pa ta uvrstitev nikakor ni neproblematična. Avtorica se namreč sprašuje:

[A]li lahko učinek njene dramatike zvedemo na jezikovni učinek in kombiniranje jezikovnih plasti, učinke medbesedilnosti in samonanašalnosti ali raje na pazljivo samorefleksivno skonstruiranost teksta s pazljivim doziranjem in izvabljanjem učinka zgodbe na gledalca / odgovor je niansiran in kompleksen, variira od teksta do teksta in je spet odvisen od razmerja med didaskalijami in replikami, njihovo razporeditvijo, osmišljenostjo in usmerjenostjo narativa. (»Dramska«122)

Ker gre za v slovenskem prostoru dodobra uveljavljene pojme, kot so postdramsko gledališče, estetika performativnega, ne več dramski tekst, rapsodični gon gledališkega teksta, jih bomo tu obnovili le v grobem, kolikor je potrebno za našo raziskavo. Bistvo vseh teh premikov, ki jih dobro povzema Tomaž Toporišič v svojem članku »(Ne več) dramski gledališki tekst in postdramsko gledališče«, je paradigmatični premik v gledališču konec šestdesetih let prejšnjega stoletja. V ta čas tako Hans-Thies Lehmann (prim. Postdramsko gledališče) kot Erika Fischer-Lichte (Estetika performativnega) locirata začetke sodobnih pogledov na gledališke uprizoritve. Lehmann v sodobnem gledališču opaža detronizacijo gledališkega teksta, ki sedaj postane le en od gledaliških 
elementov, s katerimi se gradi gledališki dogodek kot nekaj, kar se zgodi med izvajalci in gledalci vsakokratne predstave. Besedilo tako postane skrajno odprto, razpoložljivo in predvsem nima več referencialne narave, pač pa postane samorefleksivno. Kot lucidno povzema Tomaž Toporišič:

Toda za Lehmanna postdramsko gledališče kot osvoboditev od modela trizvezdja ne pomeni gledališča brez povezave onstran drame. Je zgolj proces razpada, demontaže in dekonstrukcije v sami drami. Prihodnost gledališča po drami vidi kot prihodnost gledališča onstran primata dramskega avtorja oziroma kot gledališče po verigi kriz dramskega avtorja, kot zaporedje etap samorefleksije, dekompozicije in ločevanja dramskega gledališča. (»(Ne več) dramski« 182)

Erika Fischer-Lichte detektira isti proces, a se osredotoči na gledališko uprizoritev. Slednja se po t. i. performativnem obratu ukvarja s samonanašalno feed-back zanko, še natančneje, $\mathrm{z}$ vprašanjem, kako na to zanko vplivajo posamezni elementi uprizoritve. $\mathrm{V}$ ospredju torej ni več gledališko besedilo, ki bi ga bilo treba postaviti na oder in naj bi kar najverneje odražalo neko temo/dogajanje, ki je seveda njegova referenca, pač pa gre za vzpostavljanje dogodka. Za razmere, v katerih postane bistvena soprisotnost akterjev in gledalcev, med katerimi se nekaj zgodi, slednje pa omogoča emergenco ${ }^{2}$ pomenov.

Jelinekova - tako kot Müller - v svojih tekstih razvija novo teatralnost, ki je drugačna od teatralnosti dramskih besedil. Ne gre več za dramatično teatralnost, ki je namenjena ustvarjanju možnih referentov njihovih znakov, ampak za analitično teatralnost, ki je samorefleksivna in ni več namenjena odrsko-fikcijski prezentaciji, ampak se vzpostavlja kot interakcija - Fischer-Lichtejeva bi rekla performativno dejanje predstave kot interakcije med izvajalci in gledalci, za katero je značilna avtopoetična zanka feedbacka, ki provocira in integrira emergenco - med akterji in gledalci. (»(Ne več) dramski«184)

Besedila, ki torej radikalno dekonstruirajo dramsko formo in vanjo vnašajo tako epske kot lirske prvine, Gerda Poschmann imenuje ne več dramski teksti, Jean-Pierre Sarrazac pa govori o konceptu rapsodije. Gre za besedila, ki razširjajo svoje možnosti in konstruirajo nove forme z njeno navidezno dekonstrukcijo. »Gledališče, drama, ki je pogledovala k romanu, pesmi, eseju, da bi se znova in znova osvobajala tistega, kar je bilo vedno njeno prekletstvo: njen status ,kanonske' umetnosti« (Sarrazac 24).

Vendar pa nam tu ne gre toliko za poglobljeno razpravo o krizi dramske pisave v zadnjih 60 letih kot pa za iskanje nadaljnjega razvoja, ki ga Birgit Haas detektira ob novejši nemški dramatiki, katere predstavnica je tudi Dea Loher. Za te avtorje in njihove drame je sicer značilna izkušnja ne več dramskega in s tem dekonstrukcije forme, a obenem

2 Erika Fischer-Lichte v Estetiki performativnega govori o avtopoiesis in emergentnosti kot o dveh ključnih lastnostih sodobnih uprizoritev. Pri tem razume emergenco tako, da konstrukcija pomenov ne velja več po kavzalni logiki, ampak vznikne iz ritma in postavitve različnih elementov uprizoritve. »Ker se pojavljanje ter izginjanje pojavov v zadevnih uprizoritvah ni ravnalo po razumljivi in v določenem smislu napovedljivi logiki dejanj in psihologije, in ni sledilo niti drugim kavzalnim zvezam, temveč je bilo odvisno od ritmičnih vzorcev, [...] se jim je vse prikazovalo kot emergentno« (269). 
tudi ponovno vračanje fabule, subjekta in naracije ter zunanjih referentov. Še več, prav ta besedila so v nemški dramatiki pomenila nov in močan val političnega gledališča. In s kakšnimi postopki Dea Loher to doseže? »Kljub uporabi potujitvenega efekta se ne prepusti niti postmodernistični dekonstrukciji subjekta niti koncu pripovedi. Prav nasprotno, Loher gradi na konceptu revolucionarne marksistične estetike Walterja Benjamina, s katero je slednji skušal ohraniti človeškost $\mathrm{v}$ umetnosti, element človeškosti, ki bi lahko kljuboval tehničnim inovacijam njegovega časa« (Haas 74).

To dramatiko torej zaznamuje ponovno uvajanje bolj ali manj razpoznavnega dramskega subjekta, ki je nosilec govora in dejanja, predvsem pa svojega osebnega pogleda na svet, obenem pa ravno slednji gradi tudi razpoznavno zgodbo celotne drame. Ob tem seveda ne gre za vračanje $\mathrm{v}$ nekakšen psevdorealizem, ampak za skrajno fragmentarno zgodbo, ki je zaznamovana s spoznanji postmodernizma. Kot pravi Birgit Haas, avtorica

namenoma gradi občutek negotovosti kot posledico mešanice zasebnih in javnih političnih diskurzov. [...] Njeno delo je kreativno in uspešno obujanje brechtovskega gledališča v kontekstu postmoderne dobe, dobe, v kateri so ljudje ponovno zavzeli gledališki prostor. [...] Gledališče Dee Loher je gledališče opravnomočenja, politično gledališče, ki gledalca ne pusti povsem zmedenega pred podobo družbe po koncu zgodovine. (85)

Kaj je torej tisto, kar zaznamuje eno in drugo obliko gledališkega pisanja? Je med njima jasna ločnica ali se do neke mere prekrivata? Zdi se, da gre za ponovni krog krize in renesanse, ali kot to imenuje Toporišič, ujetosti med »končati« in »začeti«, ki pa se po našem mnenju odigra ob vprašanju referencialnosti. Če torej ne več dramska besedila stavijo na konstrukcijo pomena, ki je emergenten in odvisen od vsakokratne situacije ter vpletenih (akterjev in gledalcev) ter je lahko le še trening pogleda, pri katerem "postane vidna pretrgana nit med zaznavo in lastno izkušnjo« (Lehmann 308), ti dramski gledališki teksti vendarle vzpostavljajo določljive dramske osebe in zgodbo, ki ima referenta, čeprav je ta lahko zelo fragmentaren. S slednjim se ponovno vzpostavlja konkretna družbena kritika oz. kritika določenih družbenih razmerij in odnosov.

Z besedami Richarda McClellanda, ki v svoji razpravi raziskuje ravno soobstoj obeh konceptov v sodobni nemški dramatiki: »Postdramski gledališki teksti so odprti, saj zahtevajo od gledalcev, da postanejo aktivni soustvarjalci besedila uprizoritve. Gledalci ne zapolnjujejo le predvidljivih praznih mest dramske zgodbe, ampak postanejo aktivne priče, ki razmišljajo o svojem lastnem kreiranju pomenov, obenem pa so pripravljeni sprejeti prazna mesta in nedorečenost pomena celote« (4).

Dramski gledališki teksti imajo dve bistveni razločevalni lastnosti: »Prvič, dramatik ponovno postavi dramski subjekt $\mathrm{v}$ središče dramske reprezentacije. Drugič, ta besedila gradijo na modernistični in postmodernistični dediščini, ko spajajo 
kvazirealistično raziskavo človeških izkušenj s postmodernističnim nezaupanjem v resničnost kot enotno entiteto« (prav tam).

Kako je torej s tem prehajanjem med ne več dramskim in dramskim v obravnavanih besedilih Simone Semenič?

\section{Dramsko in postdramsko v Me slišiš?}

Me slišiš? je dramska trilogija, ki predstavlja v opusu Simone Semenič posebnost. Tega se zaveda tudi sama, saj v uvodu h knjigi zapiše: »Ta besedila pa so drugačne narave tako po vsebini, pisana torej za to, da jih sama izvajam, kot po obliki, ki je dramska ali pa tudi ni« (11).

Avtorica torej zazna, da gre za posebno vrsto besedil, ki so med dramskim in ne več dramskim oz. je njihov status vsaj bolj nedoločljiv kot pri drugih njenih delih. Da bi se dokopali do jasnejše slike o vsebini in formi teh treh dram, se jim bomo približali s treh vidikov: 1 . $z$ vidika položaja avtorice oz. dramske osebe; 2 . $z$ vidika dramske forme, pri čemer imamo v mislih obliko diskurza (razmerje med didaskalijami in replikami, dialogmonolog), odnos do bralca/gledalca in njegov položaj v samem tekstu; ter 3. z vidika zgodbe oz. dramskega dejanja. Prav ta določila se zdijo namreč bistvena tudi za ne več dramske oz. dramske gledališke tekste, kot smo jih predstavili v prejšnjem poglavju.

Prva drama jaz, žrtev je od vseh treh najdoslednejše avtobiografska in monološka. $\mathrm{S}$ tem imamo $\mathrm{v}$ mislih dejstvo, da avtorica skorajda ves čas pripoveduje o sebi in $\mathrm{v}$ doslednem monologu, pri čemer da slutiti, da gre za dramski tekst le z uvodno in končno didaskalijo, ki sta v kurzivi.

kratka pavza

vdih

in izdih

in potem se začne

$[\cdots]$

kratka pavza

vdih

in izdih

in potem se konča $(M e 12,13,55)$

Knjižna izdaja se v tem smislu še nekoliko razlikuje, saj je v njej avtorica napisala spremno besedilo, ki pa ni zgolj na začetku knjige, ampak se raztegne čez celoto, tako da sproti pojasnjuje okoliščine nastanka dram. Ta pojasnila predstavljajo metabesedilo 
in uvajajo pripovedovalca ter posredniško raven v komunikacijski shemi, skratka predstavljajo močno epizacijo, ki bralcu še zaostri avtoričino poanto, razkriva njeno avtopoetiko in življenjsko filozofijo, pojasnjuje pa tudi nastanek in nadaljnjo usodo vseh treh dram. Prvi tak komentar se glasi: »Tukaj moram prekiniti. Samo da ti povem, da je ta Vesna prav tista Vesna, ki mi je v dimenziji brez božjasti namenila haljo in epruveto in Inštitut Jožefa Štefana. Do božjasti pa še pridem. Beri dalje« (Me 15).

še me dej je že nekoliko drugačna. Še vedno gre za Simono Semenič, torej avtorico samo, a predmet njenega zanimanja je sedaj avtorica kot dramska oseba, ki je vpeta v sodobno gledališko produkcijo t. i. neodvisne scene in pred nami razkriva vse skrivnosti subvencij in birokratskih postopkov. Celotna drama je »še ena izmed nočemvrnitidenarja predstav« (Me 60), predstav, ki so dobile subvencijo in jih je potem treba realizirati, da bi upravičili stroške, čeprav projekt nikakor ni domišljen in narejen, kot so si ga ustvarjalci prvotno zamislili. Didaskalij je veliko več, saj opisujejo dogajanje in v njih avtorica razmišlja o razmerju med odrom in publiko. Še več, tu je tudi neposredni nagovor gledalcu oz. vživljanje v gledalca, ki ga srečamo v njenih kasnejših dramah (npr. mi, evropski mrliči). Avtorica je tako obenem dramska oseba, avtorica/režiserka in tista, ki bralca/gledalca zapeljuje, da vstopi v dramo in jo soustvarja.

spoštovani publikum, medtem ko prihajaš,

te opazujem

zagledam te prej kot ti mene

sedim ob oknu, pri blagajni gledališča

[...]

nasmehnem se ti

nekdo me fotografira

sem malce hudomušna

hi hi hi ha ha ha

lepo nama je, a ne, da nama je lepo

tu sem

zate, spoštovani publikum $(M e 58,59)$

Tako ga neposredno nagovarja, naj bo aktiven, naj se odloči sodelovati v dogodku.

čakam, če se odločišs oditi

če je v tebi kak provokator, ki bo to naredil

pa ne bi rada, da greš

tudi če, ja, sprejmem vse posledice svoje

hudomušne igre 
ker - kot rečeno - ne želim vrniti denarja

na tem mestu se ti hudomušno nasmehnem (Me 63)

Na koncu gledalec/bralec tudi postane del gledališkega dogodka.

medtem, ko ti nosim vampe, printam besedilo

medtem ko ješ vampe, ti dam besedilo v roke

besedilo, ki je hkrati tudi gledališki list in letak, na koncu, poglej

gledaš me, kaj s tem

ja, beri, ne, kaj me gledaš

glej $v$ besedilo, ne vame

to je del predstave, da zdaj v miru poješ

vampe in da v miru prebereš besedilo (Me 96)

Avtorica na ta način uvaja dialog, ki pa ni več dialog med dramskimi osebami, ampak med odrom in avditorijem. Avtopoetska feed-back zanka, ki je sicer značilna za vsak gledališki dogodek, je sedaj tematizirana. Besedilo jo prevprašuje, skuša uravnavati ali vsaj izpostavlja nekatere elemente, ki jo konstituirajo (npr. nagovori gledalcev, tematiziranje gledalčevih občutij, njegove vloge v predstavi). Vendar pa to sodelovanje gledalca, kot opazi Katja Čičigoj, ni povsem arbitrarno, pač pa ga precej usmerja avtorica: »Nevarnost arbitrarnosti pomena tako nadomesti pragmatična delna določitev učinka: znotrajtekstualno režiranje situacije, v kateri je gledalec potisnjen v izkustvo con nedoločenosti končnega učinka dogodka« (65).

S tem Simona Semenič kot dramski lik postane trdnejša oz. jasnejša in bolj enovita. Koherentnost ji zagotavlja najprej dejstvo, da gre za avtobiografsko besedilo. Biografija avtorice je torej tista zunanja referenca, ki to dramsko osebo definira in ji nudi vsebinski kontekst. Poleg tega gre za to, da je sodelovanje gledalca režirano. Možnosti njegovega sodelovanja so omejene in vnaprej predvidene, zato se število možnih interpretacij omeji, kar nas pelje v bližino koncepta dramskega teksta. Vendar pa je to le ena plat tega razvoja. Ista dramska oseba namreč obenem postaja bolj razdrobljena, saj se avtobiografski pripovedi oz. dejanju pridružujejo še vprašanja narave predstave, odnosa med igralcem in gledalcem ... V fiktivni dramski svet poleg tega vstopa napoved drugih igralk, ki naj bi nastopile, čeprav na koncu do tega ne pride: »poleg mene v vlogi mene nastopajo še tri igralke/ - medea novak, lara jankovič in damjana černe« (Me 60).

V tretji drami iz knjige Me slišišs?, ki je bila pod naslovom drugič krstno izvedena v klubu Gromka 12. oktobra 2004, je pomenljiv že sam začetek, saj ima od vseh treh dram le ta zapisan čas, kraj dogajanja in seznam dramskih oseb. Pod dramatis personae 
piše: »simona semenič, Ti« (Me 98). Dialoški partner, ki se v besedilu oblikuje kot spoštovani publikum že v še me dej, postane sedaj kar dramska oseba. Bralec/gledalec dobi v besedilu svoje mesto, svojo vlogo. V nadaljevanju drame gre za radikalizacijo postopkov, ki smo jih že opisali ob še me dej. Avtorica se postavlja v različne vloge, ki segajo od dramske osebe, ki govori svojo pripoved v monologu, do dramatičarke, ki razmišlja o dramskih situacijah, usmerja dogajanje, ugiba o reakcijah publike ali pa jih kar napoveduje oz. zahteva.
dramatis persona simona semenič vstopa
rada bi si predstavljala, da vstopam graciozno
in da vse onemi, ko se pojavim
rada bi si predstavljala, da se zrak zgosti in čas
ustavi, ko raciozno stopim predte
ali jebiga
zmatrana sem ko pes, spala nisem skoraj nič, cel
dan sem imela vaje in potem sem 45 minut
tekla (Me 99)

Aktivno sodelovanje gledalcev je sprva želja: »morda splezaš na ta visoki oder in stopiš do mene/ in morda mi pomagaš zavihati rokav in namestiti / uno manšeto za merjenje tlaka« (102), kasneje pa že zapoved: »a lahko prosim vzamete tisti karton in flomaster / in gor napišete rezultate« (104). Monolog se razvije v nekakšen kvazi dialog z gledalcem, ki se odziva pričakovano. Ob tem pa seveda prihaja tudi do stopnjevanja čustev oz. primerov avtoričinih življenjskih tegob, ki na treh mestih od gledalca zahtevajo tudi denarne prispevke. S slednjimi Semenič meri uspešnost svojih preživetvenih taktik, lahko pa bi rekli, da obenem meri moč in prisotnost povezave med odrom in avditorijem, torej prisotnost samonanašalne feed-back zanke. V zadnjem poskusu zaključi: »no, pa smo / mislim, da mi je le uspelo nekoliko napredovat / nekoliko izpopolnit svojo taktiko preživetja / vse, kar človek na koncu koncev potrebuje, je / podoba v zlatu« (153). In zdi se, da je to tisti stik, ki ga je avtorica ves čas iskala. Pa ne v smislu, da bi ji šlo za denar, ampak za povezavo, sočutje, razumevanje: »zdaj me razumeš tudi, če sploh ne spregovorim« (prav tam).

Avtorica je torej v vseh treh dramah glavni lik, saj gre za avtobiografske tekste, ki jih izvaja sama na odru. Povezava z realno osebo in faktičnim kontekstom je torej močno prisotna, s tem pa tudi reprezentacija besedila. Njihova prevladujoča oblika je monolog, a kljub temu lahko opazimo v tem pogledu določen razvoj. Če je šlo v jaz, žrtev za enovit lik, ki mu celoto zagotavlja tudi avtorica s svojo lastno biografijo, ta lik v še me dej in drugič razpada. Cepi se na več komunikacijskih ravni. Prevzame namreč tudi vlogo avtorice, ki v didaskalijah opisuje dogajanje, razmišlja o svojem 
početju itd., predvsem pa ustvarja vedno močnejšo vez z bralcem/gledalcem. Slednji

$\mathrm{v}$ drugič postane celo ena od dramskih oseb, s čimer se ta kvazi dialog, kvazi zato, ker Ti nima nobene replike in je jasno, da gre za gledalca. Gledalec je seveda v vsaki uprizoritvi udeležen kot partner v komunikaciji, a praviloma ni dialoški partner, še manj pa je dramska oseba. Vendar se zdi, da je prav z drugič postal ta odnos za Simono Semenič bistven. Kot lahko vidimo v nekaterih njenih kasnejših besedilih, je začela pisati in misliti drame skozi prizmo gledalca. $V$ tem položaju postaja pozicija avtorice bolj negotova in odvisna od vsakokratnih gledalcev/bralcev. Slednje kaže na to, da je $v$ teh besedilih še vedno močno prisotna dediščina postdramskega. Vendar pa ni zato učinek njenih besedil nič manjši. Prej nasprotno, bralec/gledalec je močneje nagovorjen, potegnjen v dogajanje. Pri tem na videz dobiva več svobode in svobodno soustvarja gledališki dogodek ali vsaj lastno interpretacijo. Koliko je to res svoboda? Je dogajanje res povsem fragmentarno in sili gledalca k emergenci, torej $\mathrm{k}$ povsem naključnemu vznikanju pomenov? Da bi se lahko dokopali do tega, moramo premisliti še dva vidika vseh treh dram.

Nekaj opažanj o dramski formi smo zapisali že zgoraj. Gibljejo se od monologa v jaz, žrtev do nekakšnega dialoga med Simono Semenič in Ti v drugič, pri čemer seveda ne gre za pravi dialog, saj Ti nima nobene replike, je pa ves čas naslavljan in od njega se pričakujejo nekatera dejanja kot reakcije na replike Simone Semenič. Vendar pa nas tu nadalje zanima, kako se avtorica giblje med lirskimi, epskimi in dramskimi prvinami teksta. Kako jih torej meša med seboj? Tu sledimo njenemu lastnemu namigu v uvodu knjige, ko zapiše: »To, kar bereš, ni roman, tudi gledališko besedilo ni. Je torej - kaj? Sem jaz, ki se poskušam pogovarjati s tabo, je topla dekica, je kavč« (8).

Vse tri drame so izrazito avtobiografske. Njihovo dogajanje opisuje avtoričino življenje, še več, izpoveduje ga avtorica sama, ki je drame kot performanse tudi izvedla v letih 2007, 2009 in 2014. Govori torej iz sebe in o sebi. Med njo in predmetom ni nikakršne distance, kar kaže na lirski subjekt. A ta se bliža dramskemu že v še me dej, še bolj pa v drugič, saj je Simona Semenič tam dramska oseba, ki očitno komunicira s kolektivnim sprejemnikom, ki ga imenuje »dragi publikum« oz. »Ti«. Vendar pa se dejanje ne odvija pred nami v neposredni sedanjosti, ampak je v jaz, žrtev ves čas, kasneje pa večinoma, oddaljeno od subjekta v bolj ali manj daljno preteklost. Ta drža je seveda epska. Zakaj je vse to pomembno? Dramski subjekt tako ni več povsem fragmentaren, saj mu trdnost in koherenco zagotavlja avtoričina biografija. Poleg tega sama oblika performansa uvaja močno prisotnost realnega oz. faktičnega sveta, ki predstavlja zunanjo referenco dogajanja. Referencialnost oz. prikazovanje nečesa, kar predhaja gledališkemu dogodku in je vpisano v dramsko besedilo, se sedaj v veliki meri vrača.

Zanimivo se zdi, da je ta mešanica lirskega, epskega in dramskega pravzaprav osnova za besedilo, ki ustvarja izrazito napetost. V bralcu/gledalcu vzbuja močne občutke. 
Giblje se torej od sočutja, ki prevladuje v jaz, žrtev, do sodelovanja, morda celo odpora do »družbe jahačev«, kot aktualno družbeno situacijo imenuje avtorica, in zavzemanja kritične drže. Skratka, drugič uspe posredovati močno politično sporočilo skozi izrazito intimno zgodbo in s pomočjo številnih prijemov postdramskega gledališča.

V članku »Dramska pisava po postdramskem« pa Tomaž Toporišič ob dramah Anje Hilling, Milene Marković in Simone Semenič detektira tri vrste preseganja ne več dramskih besedil: nezmožnost komunikacije in razstavljanje telesa in glasu ob Anji Hilling, kjer dialog in didaskalije razpadejo in se pomešajo, dekonstrukcijo in rekonstrukcijo reprezentacije realnosti ob dramah Simone Semenič, kjer gre za številne postdramske postopke, ki pa jih avtorica sestavlja $\mathrm{v}$ učinkovite kritične tekste, ter kontaminacijo z lirskim in epskim ob delih Milene Marković. Zdi se, da ob obravnavanih dramah srečamo vse te lastnosti. Gre namreč za tesno prepletanje dramskega $\mathrm{z}$ lirskim in epskim, za vedno bolj zabrisano mejo med replikami in didaskalijami ter na koncu za fragmentarizacijo, vpletanje gledalca v sam dogodek in manipulacijo čustev, ki naj producira pomen. Koliko je ta pomen konsistenten in usmerjan s strani dramatičarke, smo že pokazali ob analizi dramske osebe in monologa/dialoga, ki se s prehajanjem od fikcije $\mathrm{k}$ realnosti približujeta dramski obliki besedila.

Kako pa je z dramskim dejanjem? Gre za povsem odprto dogajanje, ki mu mora pomen pripisati vsak recipient sam, ali pa besedilo ponuja usmeritve, ki vodijo recepcijo? Čeprav so vsa tri besedila izrazito fragmentarna in na videz pomensko odprta, vendarle vsebujejo močno rdečo nit, avtoričino biografijo, ki jih drži skupaj. Ker drame gradijo na realnem življenju Simone Semenič, njegovo razumevanje nikakor ni povsem prosto. Gradi se na njegovem čustvenem odzivu na vse avtoričine zdravstvene, finančne in ustvarjalne tegobe.

Čeprav sočustvuje z njo in ga Semenič z vsako dramo bolj vpleta v dogajanje, ne more ostati na tej intimni ravni. Avtorica se na več mestih predaja samosmiljenju in apatiji: »si mislim, edina stvar, ki jo lahko poskusim / ki mi še preostane / ki me še reši / je to, [...] da sproduciram še kako diagnozo / in da lahko vpišem novo epizodo v samoizpoved / žrtve« $(54,55)$. Zato se sprejemnikova stiska in sočutje bržkone sprostita v kritiko avtoritete oz. sistema, ki avtorici povzroča vse te težave. Kot pravi avtorica sama: »Skozi osebne pripetljaje ti trije teksti bolj ali manj bentijo čez sistem, v katerem trenutno živimo« (10). Slednji pa je »ne kočijaška združba, jahaška združba naj bo. Saj jahači tudi držijo vajeti v rokah, aneda« (12).

V jaz, žrtev gre za spoznanje, da je avtorica žrtev številnih absurdnih medicinskih postopkov, ki skušajo enkrat za vselej odpraviti njene diagnoze (močenje postelje, genitalni herpes in božjast). To se stopnjuje v knjižni izdaji, kjer avtorica s komentarji še zaostri opisane situacije. Tako npr. pripoveduje o operaciji glave, ki so ji jo opravili 
leta 1991 pri 16 letih, da bi ji, kot ji je zagotovila zdravnica, enkrat za vselej odpravili epilepsijo, a je bila posledica tega posega pojav res hudih napadov. V komentarju nam razkrije, da je poseg $\mathrm{v}$ njenih izvidih zaveden kot eksplorativna kraniotomija, kot diagnostični poseg, s katerim naj bi raziskali stanje bolezni ter se odločili o nadaljnjem zdravljenju. Ob tem zaključi: »Tam zgoraj so se torej igrali zdravnike. Če bi se zdravnike igrali tam spodaj, potem bi to bila zloraba, ker so se jih igrali tam zgoraj, je pa eksplorativna kraniotomija« (30).

še me dej je t. i. nočemvrnitidenarja predstava, ki jo avtorica mora oddelati, da upraviči prejeto subvencijo. Fragmentaren tekst, ki meša besedilo prijav na razpise, različnih dodatnih pojasnil, prošenj ter zahtevkov v postopku izbora in financiranja $\mathrm{s}$ komentarjem dogajanja $\mathrm{v}$ živo, je nekakšen kolaž, ki sili recipienta $\mathrm{v}$ to, da mu sam pripiše pomen. Vendar pa ta ni povsem poljuben, saj ves čas kaže na težke produkcijske pogoje in s tem razkriva različne taktike preživetja nevladne produkcije ter njenih akterjev, ki so usmerjene predvsem $\mathrm{v}$ hiperprodukcijo, s tem pa pogosto tudi v površnost in hitre rešitve. Ena takšnih je pričujoči tekst/performans in avtorica tega nikakor ne zanika:

ker vam ni treba ostat, nič katarzičnega ni pred

vami nocoj

razen pač to, da zveste, zakaj vampi

in da si jih privoščte

v glavnem, tudi če se vi odločite it, bom jaz še nekaj časa ostala, ker moram pač to oddelat (63)

Seveda pa obenem gledalcu spretno ponudi tarčo njegovega nelagodja v sistemu, saj so prav način subvencioniranja in pičle subvencije razlog, da kljub mednarodnemu uspehu (predstave ni mogla narediti zaradi številnih angažmajev $v$ tujini in na največjih festivalih pri nas) in nedvomni uveljavljenosti svoje dramatike ne more živeti od svojega dela.

V drugič je rezultat podoben, a taktika je drugačna. Gledalec/bralec je veliko bolj neposredno vključen v dogajanje - vpisan je kot »Ti« v seznam dramskih oseb, naprošen je za pomoč pri merjenju krvnega tlaka ... zapisuje rezultate in prispeva denar za povečanje avtoričinega proračuna. Poleg tega se sedaj Simona Semenič ne kaže več neposredno kot žrtev. Ta je sicer še vedno prisotna najprej kot odmev prejšnjih dveh besedil, nato pa tudi prek vseh njenih diagnoz in finančne stiske, ki se vlečejo kot lajtmotiv, vendar je tokrat njen odnos diametralno nasproten.

torej, žrtev je bila predstava o nekaterih mojih

boleznih, težavah, tegobah, kakor sem jih

poimenovala v letu 2007 
danes jih ne imenujem več tako

danes jih imenujem blagoslov

ker sem se naučila, da so stvari, ki morda na prvi

pogled zgledajo kot breme, pravzaprav darila

darila, ki jih moraš prav odpret, da bi postala

opora in smerokaz $(111,12)$

Njen pristop, ki je prej temeljil na vlogi žrtve in vzbujanju sočutja, je postal aktiven. Sedaj vzame zdravje v svoje roke, teče, neha kaditi ... Seveda pa se ta aktivizem prenese tudi na njeno profesionalno in ustvarjalno življenje. Prav drugič je predstava o taktikah preživetja na vseh ravneh. Tako kot pacientka štrajka, »dokler združba jahačev ne uredi javnega zdravstva tako, kot se eni pravni in socialni državi spodobi« $(138,39)$. Poziva pravzaprav k spremembi družbe, ki bi prinesla kakovostno zdravljenje vsem (plačana bolniška odsotnost za zaposlene in samozaposlene), osnovno finančno neodvisnost oz. dostojen mesečni dohodek, da ljudje ne bodo pod stresom in zato zbolevali, ter financiranje npr. psihoterapije s strani zdravstvenega sistema.

Intimna zgodba se tu preveša v družbeni program, do katerega se mora sprejemnik opredeliti. Prav tako provokativen je zaključek, ko Semenič svoje telo, zaznamovano $\mathrm{z}$ diagnozami in posegi, najprej razstavi pred avditorijem, potem pa ga odene $\mathrm{v}$ zlato (od spodnjic do obleke in sandalov) ter prek tega dejanja, ki po eni strani spominja na emancipacijo oz. spoznanje lastne vrednosti, po drugi pa na prostituiranje, pride do zadnje nabirke denarja. Sledi replika:

no, pa smo

mislim, da mi je le uspelo nekoliko napredovat

nekoliko izpopolnit svojo taktiko preživetja

vse, kar človek na koncu koncev potrebuje, je

podoba v zlatu (153)

Tako je povsem jasno, da te drame niso povsem pomensko odprte. S svojo strukturo bralcu/gledalcu usmerjajo recepcijo in uspejo ustvariti močno družbenokritično sporočilo. Slednje pa nikakor ni agitatorsko ali plakatno, ampak temelji na iskreni intimni zgodbi ter spretni manipulaciji čustev, ki jih dosega avtorica s številnimi postdramskimi prijemi. 


\section{Sklep}

Na tej točki lahko skušamo odgovoriti na izhodiščni vprašanji. Imajo te drame še vedno zunanjo referenco? Gre torej za reprezentacijo ali prezenco? Na prvi pogled se zdi odgovor enostaven. Seveda vsa tri besedila, objavljena v Me slišišs?, vzpostavljajo neko zunanjo referenco. Najprej se referirajo na avtoričino biografijo in njeno realno življenje. Tako se neposredno nanašajo na probleme današnje družbe, predvsem na vprašanje avtoritete, delovanja zdravstvenega sistema in področja kulturne produkcije.

Vendar pa bralcu/gledalcu te drame ne izrisujejo sveta, ki naj bi bil ločen od njega in naj bi se vanj vživljal ali o njem razmišljal, pač pa ga Semenič nenehno zapleta v dramsko dogajanje. Od gledalca zahteva aktivno vlogo, pa naj bo to neposredna akcija ob živi uprizoritvi ali pa čustveni odziv. Ta odziv odločilno gradi razumevanje drame, kar pomeni, da gre za nekakšno vzajemno učinkovanje reprezentacije in prezence. Kar smo razumeli kot nasprotje (prim. npr. Fischer-Lichte), se vrača v nov krog kot spoj. Dramski tekst ponovno prenese referencialnost in je sposoben sproducirati koherentno sporočilo, a je obenem zaznamovan prav z izkušnjo postdramskega. $\mathrm{Ne}$ računa več na gledalčevo estetsko distanco in brezinteresno ugajanje v Kantovem smislu, niti na distanco kot posledico potujitvenega efekta (Brecht), ki naj bi gledalca obdržala v območju racionalnega premisleka, ampak angažira recipienta na čustveni ravni ter ga postavi $v$ vlogo soustvarjalca pomena, čeprav to sodelovanje $v$ določeni meri usmerja. Rezultat je močna družbena kritika, ki pa se gradi prek osebne izkušnje, ki gledalca angažira na čustveni ravni.

Da bi dobili boljši vpogled v nihanje Simone Semenič med postdramsko in dramsko pisavo, bi morali pregledati tudi druge njene drame, ki v večji meri temeljijo na dialogu in didaskalijah, predvsem pa na fiktivnih zgodbah in junakih, vendar to presega naš trenutni namen. Dejstvo je, da Simona Semenič, podobno kot nekateri drugi evropski dramatiki, išče nove oblike pisanja, ki bi ob močnem učinkovanju na gledalca in njegovem angažmaju lahko ubesedile jasna sporočila o nas samih in o svetu, v katerem živimo. 
Čičigoj, Katja. »>Naredite lahko karkoli, a biti mora pravilni karkoli.» Odprto delo tekst kot dogodek.«Slovenska dramatika, uredila Mateja Pezdirc Bartol, Znanstvena založba Filozofske fakultete (Obdobja, 31), 2012, str. 61-68.

Fischer-Lichte, Erika. Estetika performativnega. Prevedel Jaša Drnovšek. Študentska založba, 2008.

Haas, Birgit. »History through the Lens of the Uncertainty Principle: Dea Loher's ,Leviathan'« The Journal of the Midwest Modern Language Association, letn. 39, št. 1, 2006, str. 73-87.

Lehmann, Hans-Thies. Postdramsko gledališče. Prevedel K. J. Kozak, Maska, 2003.

Leskovšek, Nika. »Dramska pisava za današnji čas.« Tri drame, Simona Semenič, Beletrina, 2017, str. 113-141.

McClelland, Richard. »Between Postdramatic Text and Dramatic Drama: Recent German Playwriting by Lukas Bärfuss and Katja Brunner.« Humanities, letn. 9, št. 3, 2020, str. 1-13, doi.org/10.3390/h9030061.

Poschmann, Gerda. Der nicht mehr dramatische Theatertext: Aktülle Bühnenstücke und ihre dramaturgische Analyse. Niemeyer, 1997.

Sarrazac, Jean-Pierre. »Kriza drame.« Drama, tekst, pisava, uredila Petra Pogorevc in Tomaž Toporišič, Mestno gledališče ljubljansko, 2008, str. 13-25.

Semenič, Simona. Me slišiš? KUD AAC Zrakogled, 2017.

—. Tri drame. Beletrina, 2017.

Toporišič, Tomaž. »(Ne več) dramski gledališki tekst in postdramsko gledališče.» Primerjalna književnost, letn. 30, št. 1, 2007, str. 181-189.

—. »(Ne več) dramsko v sodobni slovenski dramatiki (Jovanović, Ravnjak, Potočnjak, Skubic, Semenič).«Slavistična revija, letn. 63, št. 1, 2015, str. 89-102.

- »Dramska pisava po postdramskem: Anja Hilling, Milena Marković in Simona Semenič.« Slavistična revija, letn. 68, št. 2, 2020, str. 109-124.

Zajc, Ivana. »Elementi monodrame in avtobiografskosti v besedilih Simone Semenič.» Amfiteater, letn. 7, št. 2, 2019, str. 80-95. 